\title{
A quest to find good primers for gene expression analysis of Candida albicans from clinical samples
}

\author{
Gabriela C. Alonso, Ana C. Pavarina*, Tábata V. Sousa, Marlise I. Klein \\ Department of Dental Materials and Prosthodontics, São Paulo State University (Unesp), School of Dentistry, Araraquara, São Paulo, Brazil
}

\section{A R T I C L E I N F O}

\section{Keywords:}

Candida albicans

Biofilm

Virulence genes

Primers

qPCR

\begin{abstract}
A B S T R A C T
Biofilm production contributes to several human diseases, including oral candidiasis. Among the Candida species, Candida albicans is the most prevalent. The expression of virulence genes is implicated in the pathogenic potential of Candida biofilms. However, the evaluation of microbial gene expression from in vivo biofilm samples is not trivial, specifically, assessment via quantitative PCR (qPCR) can be a challenge because of several species present in clinical samples. Hence, the necessity of primers specificity. The aim of this study was to evaluate through in silico and in vitro analyses the specificity of published primers and newly designed primers for $C$. albicans virulence genes: ALS1, CAP1, CAT1, EFG1, HWP1, LIP3, PLB1, SAP1, SAP4, SOD1, SOD5 and ACT1 (normalizing gene). In silico analysis was performed through a PubMed search of articles with primer sequences that evaluated gene expression of $C$. albicans. Then, the sequence similarity of twenty-eight primers was checked through BLASTn and ClustalW2. The analysis of secondary structures was performed using mfold. When the primers did not present satisfactory characteristics (absence of secondary structures, not discrepant Tm of forward and reverse sequences and specificity) following in vitro analysis (i.e., end point PCR), new primers were designed using Beacon Designer ${ }^{\mathrm{TM}}$ and sequences obtained from the "Candida Genome Database". The selected primers were tested in vitro by end point PCR using a panel of genomic DNA from five different Candida species (C. albicans, Candida glabrata, Candida dubliniensis, Candida krusei, and Candida tropicalis). The resulting PCR products were visualized on agarose gel. qPCR reactions were performed to determine primers' optimal concentration and PCR efficiency. End point PCR demonstrated that published primers for the SAP1 and HWP1 were specific for $C$. albicans and the one for SOD1 reacted with $C$. albicans and $C$. dubliniensis. The sequence of primers designed for ACT1, ALS1 and HWP1 genes were specific for C. albicans, while the ones for CAP1, CAT1, EFG1, LIP3, and PLB1 were detected in C. albicans and C. dubliniensis. After optimization, all primers presented a single peak on melt curves, correlation coefficient of $\cong 1$ and qPCR reaction efficiency of $90-110 \%$, with slope of $\cong-3.3$. Therefore, these primers should be suitable for future gene expression analyses from clinical samples.
\end{abstract}

\section{Introduction}

Oral candidiasis is the most common soft tissue fungal infection of the oral cavity in humans caused by Candida spp. (Akpan and Morgan, 2002; Sardi et al., 2013). An overgrowth of these fungi can cause superficial, cutaneous, mucosal, and invasive infections (Sardi et al., 2013). Candida albicans is considered the most prevalent pathogenic species in the oral microbiota (Kulak et al., 1994), growing as yeast, pseudohyphal or hyphal forms. The yeast morphology of $C$. albicans is considered commensal in healthy humans but can cause systemic infection in immunocompromised patients, mainly because of their ability to adapt to different niches (Sardi et al., 2013). Even though the yeast form is considered a less harmful morphology, there is an increase in resistant of this fungus to antifungal drugs, contributing to human disease once the immune system is repressed, C. albicans can prevail and act as an opportunistic fungus, causing infection especially when the host microbiota is modified by certain predisposing factors (Akpan and Morgan, 2002; Nobile and Johnson, 2015). Besides the high prevalence of $C$. albicans, other species have been detected in human infections. The most commonly described are: Candida glabrata, Candida dubliniensis, Candida krusei, and Candida tropicalis (Lyon et al., 2006). In addition to these species, Candida auris is an emerging multidrug resistant fungal pathogen (Chatterjee et al., 2015).

A major virulence factor of $C$. albicans is its capacity to form biofilms on biotic or abiotic surfaces (Gulati and Nobile, 2016; Mayer et al., 2013). Biofilms can be described as surface-associated communities of

\footnotetext{
* Corresponding author at: Department of Dental Materials and Prosthodontics, São Paulo State University (Unesp), School of Dentistry, Rua Humaitá n 1680, Araraquara, São Paulo 14801-903, Brazil.

E-mail address: pavarina@foar.unesp.br (A.C. Pavarina).
} 
microorganisms embedded within an extracellular matrix (Silva et al., 2011). The biofilm formation by Candida spp. is an important virulence factor because it protects microbial cells from host immune responses, limits the penetration of substances through the matrix, thereby conferring significant resistance to conventional antifungal therapy (Gulati and Nobile, 2016; Silva et al., 2011). In addition to the ability to form biofilms, there are others important factors to the virulence of $C$. albicans: the morphological transition between yeast and hyphal forms; the expression of adhesins and invasins on the cell surface; thigmotropism; phenotypic switching; secretion of hydrolytic enzymes; resistance to changes in environmental $\mathrm{pH}$; metabolic flexibility; powerful nutrient acquisition systems (glucose, lipids, proteins and amino acids); and response to oxidative stress (Mayer et al., 2013).

The increased incidence of superficial and systemic infections caused by Candida spp. has been attributed to resistance to antifungals and expression of many virulence factors that these fungi present after exposure to antifungals to infection treatment (Haynes, 2001; Sardi et al., 2013). Therefore, understanding the virulence and resistance mechanisms associated with these species is relevant. Moreover, the knowledge about the expression of virulence factors genes and how therapeutic approaches affect the expression of those genes can be an indicator of treatment/intervention effectiveness.

There are a few of methods for gene expression analysis to identify changes of expression of important virulence factors responsible for the onset and development of infection in the host and for resistance to therapeutics. Among them is the qPCR (quantitative Polymerase Chain Reaction) technique, which can quantify mRNA expression of virulence genes. An ideal PCR reaction shows high specificity, yield and fidelity (Cha and Thilly, 1993). Therefore, it is important that the qPCR primers have satisfactory characteristics (i.e., absence of secondary structures, resulting PCR product size...) and specifically anneal to improve the sensitivity of PCR. Although transcriptomic analysis using next-generation sequencing (NGS) approaches can provide an overall expression profile, subsequent validation of critical genes is almost invariably carried out by qPCR. A summary of considerations can be found in Bustin (2004) and Thornton and Basu (2011).

Therefore, to evaluate the expression of $C$. albicans genes in in vivo biofilm samples from patients, we first analyzed whether the published primers were suitable for use. Biofilms or clinical sample analysis can be challenging because several species may be present in a clinical sample and the primers need to be specific. In this context, the purpose of this study was to find and standardize published or newly designed primers for target $C$. albicans virulence genes, these primers needed to display satisfactory characteristics to be used in future in vivo studies. The primers pairs were tested through in silico and later with the in vitro tests, end point PCR and quantitative PCR.

\section{Materials and methods}

\subsection{In silico analyses of selected $C$. albicans virulence genes}

\subsubsection{PubMed searches (Performed in July of 2015)}

Initially, PubMed searches were performed to find significant genes associated with $C$. albicans virulence. The thirteen genes selected are detailed in Table 1. Subsequently, additional PubMed queries were performed using a combination of the following key words: 1) Candida albicans, qPCR, gene expression; 2) Candida albicans, specific gene name of genes listed in Table 1. The following publications were selected in which the authors described the primers and cited when these primers were target-specific for the chosen virulence genes (Alves et al., 2014; Chen and Lan, 2015; Dai et al., 2013; Green et al., 2004; Hnisz et al., 2012; Komalapriya et al., 2015; Martchenko et al., 2004; Naglik et al., 2003b; Nailis et al., 2010; Zhu et al., 2011). Next, all primers were subjected to a step wise validation approach described below.

\subsubsection{Analysis using Basic Local Alignment Search Tool (BLASTn)}

The sequences of the specific genes were obtained in FASTA format from the Candida Genome Database (http://www.candidagenome.org/) and PubMed database (for SAP1 gene). The primer sequences (forward and reverse) were identified in the downloaded gene sequence, and the predicted amplicons were analyzed using BLASTn to check sequence similarity of them to the intended target genes in NCBI (http://blast. ncbi.nlm.nih.gov/Blast.cgi) (Johnson et al., 2008) for all currently known genes in other species. The primers were also analyzed for sequence similarity by BLAST against other fungal species via "Candida Genome Database" search (http://www.candidagenome.org/cgi-bin/ compute/blast_clade.pl).

\subsubsection{Alignment of target sequences by Clustal analysis}

Clustal W2 was used to align multiple sequences (http://www.ebi. ac.uk/Tools/msa/clustalo) to evaluate the sequence similarities of primers against genes within gene families. The strength of interaction between homologous nucleotides was also observed.

\subsubsection{MFOLD}

The MFOLD program was used to detect possible secondary structures in the chosen primers and the resulting PCR products (http:// unafold.rna.albany.edu/?q=mfold/DNA-Folding-Form). This tool has as main advantages the possibility of changing the ionic conditions of the primers $([\mathrm{Na}+]$ and $[\mathrm{Mg}++])$ and desired temperatures for annealing. The parameters used for the analysis of secondary structures were: folding temperature: $60^{\circ} \mathrm{C} ;[\mathrm{Na}+]: 50 \mathrm{mM}$; and $[\mathrm{Mg}++]: 3 \mathrm{~mm}$.

Finally, all published primers were also analyzed by Beacon Designer $^{\mathrm{TM}}$ software (Premier Biosoft, version 8.14, Corina Way, Palo Alto, CA, USA). The parameters used to test were: Tm of forward and reverse $\left(50 \pm 5{ }^{\circ} \mathrm{C}\right)$; primer size $(18-24 \mathrm{bp})$; product size (80-150 bp); $\mathrm{GC} \%$ and absence of hairpins.

\subsubsection{Design of new primers}

When the published primers did not show the characteristics already described in the Introduction for clinical samples evaluation, new primers were designed by Beacon Designer ${ }^{\mathrm{TM}}$ software. The primers were designed using the following parameters: no identity with other species or gene; Tm around $50^{\circ} \mathrm{C}$; SYBR Green; primer size between 18 and $24 \mathrm{bp}$; PCR product size between 80 and $150 \mathrm{bp}$, no hairpins and GC\% (around 50\%). The designed primers were also analyzed by in silico methodology described earlier (i.e., Blastn, Clustal, Mfold).

\subsubsection{Primers selected for in vitro analyses}

Ten published primers and eight newly designed primers were selected for in vitro analyses to test their specificity (Table 2).

\subsubsection{In vitro analyses of published and newly designed primers}

All the selected primers shown in Table 2 were evaluated for specificity to $C$. albicans. The cross-reaction was evaluated through the detection of the PCR products against a panel of genomic DNA isolated from four different Candida species (C. glabrata, C. dubliniensis, C. krusei, and $C$. tropicalis) in addition to C. albicans DNA. Those primers that did not cross react with other species (except $C$. dubliniensis) were used to determine optimal concentration for $\mathrm{qPCR}$ reaction. Moreover, the detection limit for each selected primer was evaluated using $\mathrm{QPCR}$ and isolated DNA as template.

\subsubsection{Yeast strains and DNA isolation}

A panel of five reference strains of Candida spp. associated with candidiasis, was used for genomic DNA isolation. Three strains were obtained from the American Type Culture Collection (ATCC; Rockville, MD): Candida glabrata (ATCC 2001), Candida tropicalis (ATCC 4563) and Candida krusei (ATCC 6258). Candida dubliniensis (CBS 7987) was obtained from Centraalbureau voor Schimmelcultures (CBS, Utrecht, Netherlands) and C. albicans (SC5314) was obtained from Stanford 
Table 1

C. albicans virulence genes.

\begin{tabular}{|c|c|c|}
\hline Systematic name ${ }^{a}$ & Gene name & Gene description (references) \\
\hline C1_13700W_A & ACT1 & $\begin{array}{l}\text { Actin. Transcript regulated by growth phase in the induction of hyphal morphogenesis (Paranjape and Datta, 1991) and Spider biofilm } \\
\text { repressed. Gene used as a standard internal control for RT-qPCR reactions analysis (Alves et al., 2014; Komalapriya et al., 2015; Nailis et al., } \\
\text { 2010). }\end{array}$ \\
\hline C6_03700W_A & ALS1 & $\begin{array}{l}\text { Agglutinin-Like Sequence } 1 \text {. Cell wall adhesin protein that is required during in the initial adherence step acting in biofilm surface attachment. } \\
\text { It has complementary roles in biofilm formation (Finkel and Mitchell, 2011; Nobile et al., 2008). }\end{array}$ \\
\hline CR_07070C_A & ALS3 & $\begin{array}{l}\text { Agglutinin-Like Sequence 3. Cell wall adhesin protein that acts as complementary cell-cell adhesins. It is primarily expressed in hyphae (Finkel } \\
\text { and Mitchell, 2011; Nobile et al., 2008). }\end{array}$ \\
\hline C3_02220W_A & CAP1 & $\begin{array}{l}\text { Adenylate cyclase-associated protein, CAP1, is responsible for the activation of oxidative stress genes in } C \text {. albicans. Its activation induces the } \\
\text { transcription of several antioxidant genes (Enjalbert et al., 2006; Komalapriya et al., 2015). }\end{array}$ \\
\hline C1_06810W_A & CAT1 & $\begin{array}{l}\text { Catalase 1. Protect } C \text {. albicans for oxidative stress (Wysong et al., 1998). Catalase is considered the first antioxidant systems detoxification in } C \text {. } \\
\text { albicans, it catalyses the } \mathrm{H}_{2} \mathrm{O}_{2} \text { dismutation (Komalapriya et al., 2015). }\end{array}$ \\
\hline CR_07890W_A & EFG1 & $\begin{array}{l}\text { Enhanced Filamentous Growth. A transcription regulator that controlled biofilm formation in C. albicans. It is part of the hyphal regulatory } \\
\text { circuit (Hnisz et al., 2012). }\end{array}$ \\
\hline C4_03570W_A & HWP1 & $\begin{array}{l}\text { Hyphal wall protein involved in C. albicans adhesion to epithelial cells. Mediates adhesion of C. albicans to epithelial cells by functioning as a } \\
\text { substrate for a transglutaminase and has an important role in pathogenesis (Monroy-Pérez et al., 2012; Nailis et al., 2010). }\end{array}$ \\
\hline C1_09900W_A & LIP3 & Secreted lipase. Lipase is associated with biofilm growth on mucosal surfaces (Nailis et al., 2010). \\
\hline C6_01990W_A & PLB1 & Phospholipase B promotes adherence and penetration to the cell, contributing to tissue damage (Leidich et al., 1998; Naglik et al., 2003b). \\
\hline C6_03490C_A & SAP1 & $\begin{array}{l}\text { Secreted Aspartyl Proteinase 1. SAP1 is expressed in the initial stages, reflecting colonization and contribute to tissue damage because it } \\
\text { degrades proteins (Naglik et al., 2003b). }\end{array}$ \\
\hline C6_03500C_A & SAP4 & Secreted Aspartyl Proteinase 4. Associated with hypha formation and proteinase expression (Naglik et al., 2003a; Nailis et al., 2010). \\
\hline C4_02320C_A & SOD1 & Cytosolic copper- and zinc-containing superoxide dismutase (Hwang et al., 1999; Martchenko et al., 2004). \\
\hline C2_00680C_A & SOD5 & $\begin{array}{l}\text { Cu-containing superoxide dismutase. Protects the fungus against oxidative stress. Transcription factors regulate the SOD5 that regulates the } \\
\text { transition yeast-to-hyphal switch of } C \text {. albicans (Martchenko et al., 2004). }\end{array}$ \\
\hline
\end{tabular}

${ }^{\text {a }}$ Retrieved from Candida Genome Database.

Genome Technology Center (Stanford University, USA). All strains were plated on Sabouraud Dextrose Agar plates (SDA) (Acumedia, Michigan, USA) at $37^{\circ} \mathrm{C}$ for $48 \mathrm{~h}$. Then, starter cultures of each strain were prepared by transferring 5 colonies to tubes with $10 \mathrm{ml}$ of Yeast Nitrogen Base (YNB) incubated at $37^{\circ} \mathrm{C}$, for $18 \mathrm{~h}$. These cultures were diluted 1:20 into fresh YNB and incubated at $37^{\circ} \mathrm{C}$ until each strain

Table 2

Primers selected for analyses.

\begin{tabular}{|c|c|c|c|c|c|}
\hline Gene & Primers & $\operatorname{Tm}\left({ }^{\circ} \mathrm{C}\right)$ & CG (\%) & Product length & Reference \\
\hline \multirow[t]{6}{*}{ ACT1 } & F - TTTCATCTTCTGTATCAGAGGAACTTATTT & 66.9 & 41.7 & NA & Nailis et al. (2010) \\
\hline & R - ATGGGATGAATCATCAAACAAGAG & 66.3 & 41.7 & & \\
\hline & F - TGCTGAACGTATGCAAAAGG & 63.3 & 45 & 186 & Alves et al. (2014) \\
\hline & R - TGAACAATGGATGGACCAGA & 62.9 & 45 & & \\
\hline & F - ATTCGGTGAGTAATCCTA & 55.6 & 38.9 & 167 & This study (Beacon Designer) \\
\hline & R - GTATAGTCCAGATAACAACA & 55.5 & 35 & & \\
\hline \multirow[t]{2}{*}{ ALS1 } & F - CATCATTGACTCAGTTGT & 55.9 & 38.9 & 117 & \\
\hline & R - CAGTGGAAGTAGATTGTG & 56 & 44.4 & & \\
\hline \multirow[t]{2}{*}{ CAP1 } & F - AGTCAATTCAATGTTCAAG & 55 & 31.6 & 87 & \\
\hline & R - AATGGTAATGTCCTCAAG & 55.2 & 38.9 & & \\
\hline \multirow[t]{2}{*}{ CAT1 } & F - GACTGCTTACATTCAAAC & 55.1 & 38.9 & 117 & \\
\hline & R - AACTTACCAAATCTTCTCA & 55.1 & 31.6 & & \\
\hline \multirow[t]{2}{*}{ EFG1 } & F - ACGAGTAACAACTACCAT & 56.5 & 38.9 & 89 & \\
\hline & R - TATCTGCTCTTCTGACAA & 56.2 & 38.9 & & \\
\hline \multirow[t]{6}{*}{ HWP1 } & F - CTCCAAAATCATCAGCTC & 56.8 & 44.4 & 114 & \\
\hline & R - CACTAGCCAAAACAGAAG & 57 & 44.4 & & \\
\hline & F - TCTACTGCTCCAGCCACTGA & 66.8 & 55 & 248 & Alves et al. (2014) \\
\hline & R - CCAGCAGGAATTGTTTCCAT & 62.7 & 45 & & \\
\hline & F - GACCGTCTACCTGTGGGACAGT & 69.6 & 59 & NA & Nailis et al. (2010) \\
\hline & R - GCTCAACTTATTGCTATCGCTTATTACA & 65.9 & 35.7 & & \\
\hline \multirow[t]{4}{*}{ LIP3 } & F - TCTCACCGAGATTGTTGTTGGA & 65.8 & 45.5 & 68 & \\
\hline & R - GTTGGCCATCAAATCTTGCA & 63.6 & 45 & & \\
\hline & F - AGAGAATGTATGAAGTTGT & 54.9 & 31.6 & 136 & This study (Beacon Designer) \\
\hline & R - CCCTGTTCAAAGTATCTAT & 55 & 36.8 & & \\
\hline \multirow[t]{4}{*}{ PLB1 } & F - GGCATTGAACATCCTATA & 55 & 38.9 & 124 & \\
\hline & R - GGTAACTTAATAGTCTTCCA & 55.4 & 35 & & \\
\hline & F - GGTGGAGAAGATGGCCAAAA & 64.5 & 50 & 60 & Nailis et al. (2010) \\
\hline & R - AGCACTTACGTTACGATGCAACA & 67.1 & 43.5 & & \\
\hline \multirow[t]{4}{*}{ SAP1 } & F - AACCAATAGTGATGTCAGCAGCAT & 66.9 & 41.7 & NA & \\
\hline & R - ACAAGCCCTCCCAGTTACTTTAAA & 66.3 & 41.7 & & \\
\hline & F - TCAATCAATTTACTCTTCСАТTTCTAАСA & 63.7 & 27.6 & 161 & Naglik et al. (2003b) \\
\hline & R - CCAGTAGCATTAACAGGAGTTTTAATGACA & 67.6 & 36.7 & & \\
\hline \multirow[t]{2}{*}{ SAP4 } & F - AAACGGCATTTGAATCTGGAA & 63 & 38.1 & NA & Nailis et al. (2010) \\
\hline & R - CAAAAACTTAGCGTTATTGTTGACACT & 65.2 & 33.3 & & \\
\hline \multirow[t]{2}{*}{ SOD1 } & F - TTGAACAAGAATCCGAATCC & 59.9 & 40 & 396 & Zhu et al. (2011) \\
\hline & R - AGCCAATGACACCACAAGCAG & 67.7 & 52.4 & & \\
\hline
\end{tabular}

NA: not available. 
reached mid-log growth phase. Growth was monitored spectrophotometrically at $540 \mathrm{~nm}$ (optical densities were approximately 0.5 ). The cultures were centrifuged $\left(5000 \times g, 10 \mathrm{~min}, 4^{\circ} \mathrm{C}\right)$ and the supernatant discarded. Briefly, to isolate the DNA, the pellets were suspended in $0.5 \mathrm{ml}$ of Tris EDTA buffer (TE, pH 8.0) (Sigma-Aldrich Co., St. Louis, MO, USA), centrifuged $\left(10,000 \times g, 10 \mathrm{~min}, 4^{\circ} \mathrm{C}\right)$ and the supernatant discarded. The pellets were resuspended in $100 \mu$ l of TE, added $10.9 \mu \mathrm{l}$ of Lyzosim (stock $100 \mathrm{mg} / \mathrm{ml}$ ) (Sigma) and $5 \mu \mathrm{l}$ of mutanolysin (stock $5 \mathrm{U} / \mu \mathrm{l}$ ) (Sigma). The suspension was incubated at $37^{\circ} \mathrm{C}$ for $30 \mathrm{~min}$. Next, the DNA was extracted using Master Pure ${ }^{\mathrm{TM}}$ Complete DNA and RNA Purification Kit (Epicentre Technologies, Madison, Wis, USA) according to manufacturer's recommendations. Total DNA yield was quantified spectrophotometrically at $260 \mathrm{~nm}$ (DS-11, DeNovix, Wilmington, DE, USA). Protein contamination was assessed by the ratio $260 / 280$. To check integrity, the genomic DNA samples were analyzed by agarose electrophoresis (1\% agarose) (Life Technologies Corpor, Staley Road, New York, USA) with ethidium bromide $(0.3 \mu \mathrm{g} / \mathrm{ml})$ (Bio-Rad Laboratories, Hercules, CA, USA) at $60 \mathrm{~V}$ for $60 \mathrm{~min}$ and visualized using UV transillumination Bio-Rad Gel Doc System ${ }^{\circledR}$ (Bio-Rad).

\subsubsection{Primer specificity}

All primers were manufactured by ThermoFisher (Life Technologies Brasil Com Ind Prod Bio LTDA, São Paulo, SP, Brasil). Amplification of the target sequences was performed by conventional PCR using the Taq DNA Polymerase, recombinant kit (Life Technologies). A $50 \mu$ reaction mixture consisted of $1 \mu \mathrm{l}$ of $10 \mu \mathrm{M}$ primers, $1 \mu \mathrm{l}$ of $200 \mathrm{ng} / \mu \mathrm{l}$ genomic DNA of the different species (per PCR tube), $5 \mu$ of iTaq Buffer $10 \times$, $1.5 \mu \mathrm{l}$ of $\mathrm{MgCl}_{2}$ (50 mM), $1 \mu \mathrm{l}$ of dNTPs $(10 \mathrm{mM}), 40.25 \mu \mathrm{l}$ of molecular grade water and $0.25 \mu \mathrm{l}$ of iTaq DNA Polymerase $(5 \mathrm{U} / \mu \mathrm{l})$. The PCR reactions were run on a CFX96 Touch $^{\text {TM }}$ Real-Time PCR Detection System (Bio-Rad) with cycling protocol of: $3 \mathrm{~min}$ at $95^{\circ} \mathrm{C}, 30$ cycles of $15 \mathrm{~s}$ at $95^{\circ} \mathrm{C}, 50^{\circ} \mathrm{C}$ or $55^{\circ} \mathrm{C}$ or $60^{\circ} \mathrm{C}$ for $30 \mathrm{~s}$ and $72{ }^{\circ} \mathrm{C}$ for $30 \mathrm{~s}$; reactions were maintained at $4^{\circ} \mathrm{C}$. The annealing temperature was adjusted per primer. To check for correct amplicon (product PCR size) and specificity (cross reaction), the PCR products were analyzed by agarose electrophoresis ( $2 \%$ agarose) (Life Technologies).

\subsubsection{Optimal concentration of primers}

The optimal concentration of each primer pair was determined by qPCR with SYBR Green Master Mix (Life Technologies) and genomic DNA from C. albicans at a concentration of $10 \mathrm{ng} / \mu \mathrm{l}$. Each primer was tested at different concentrations (in $50 \mathrm{nM}$ increments) in the general range of $200-650 \mathrm{nM}$. The optimal concentration of each primer was considered the lowest Quantification Cycle (Cq) on a amplification plot. A $25 \mu \mathrm{l}$ final volume of reaction with $200 \mathrm{nM}$ primers consisted of $0.5 \mu \mathrm{l}$ of DNA template $(10 \mathrm{ng} / \mu \mathrm{l}), 12.5 \mu \mathrm{l}$ of SYBR Green Supermix (Life Technologies), $0.5 \mu l$ of primer set and $11.5 \mu \mathrm{l}$ of water molecular grade. All primers were tested in duplicate with NTC (no template control, where DNA was replaced with molecular grade water). The cycling protocol were: $10 \mathrm{~min}$ at $95^{\circ} \mathrm{C}, 39$ cycles of denaturation during $15 \mathrm{~s}$ at $94^{\circ} \mathrm{C}$, annealing at $50^{\circ} \mathrm{C}$ or $55^{\circ} \mathrm{C}$ or $60^{\circ} \mathrm{C}$ for $30 \mathrm{~s}$, and elongation at $60^{\circ} \mathrm{C}$ for $15 \mathrm{~s}$, with melt curve tested with gradual increase of $0.5^{\circ} \mathrm{C}$ from $55^{\circ} \mathrm{C}$ to $95^{\circ} \mathrm{C}$. The annealing temperature was adjusted for each primer. For the gene SOD1, the elongation time was of $30 \mathrm{~s}$ because of the longer amplicon size. The amplification plot, standard and melt curves were analyzed by Bio-Rad CFX Manager ${ }^{\mathrm{TM}}$ Software (BioRad).

\subsubsection{1. $q P C R$ detection limit}

After primer concentration and cycling optimization, the detection limit for each selected primer was evaluated using QPCR and serial dilution of genomic DNA of $C$. albicans as templates $(100 \mathrm{ng} / \mu \mathrm{l}$ to $0.001 \mathrm{fg} / \mu \mathrm{l})$. Each reaction was prepared with a final volume of $25 \mu \mathrm{l}$ with $0.5 \mu \mathrm{l}$ DNA template, $12.5 \mu \mathrm{l}$ of SYBR Green Supermix (Life Technologies), $0.5 \mu \mathrm{l}$ of $10 \mu \mathrm{M}$ primer set (for $200 \mathrm{nM}$ concentration) and $11.5 \mu \mathrm{l}$ of water molecular grade. All primers were tested in duplicate, along NTC. The qPCR runs were performed on a CFX96 Touch $^{\mathrm{TM}}$ Real-Time PCR Detection System (Bio-Rad) with the cycling protocol described earlier for optimization of primer concentration.

\subsubsection{2. $q P C R$ standard curves preparation and evaluation}

Standard curves for each primer was prepared based on the PCR product resulting from reactions with genomic DNA of $C$. albicans. A total of seven PCR reactions were performed for each gene and pooled together. An aliquot of each pool was used to verify the amplicons by agarose electrophoresis. Next, the remaining products was purified using QIAquick PCR Purification Kit (Qiagen, Doncaster, Vic., Australia) according to the manufacturer's instructions. After purification, the amplicons were analyzed by agarose electrophoresis and its concentrations were estimated by OD260 (DS-11 DeNovix). The number of PCR product copies/ml were calculated according to the formula describe by Yin et al. (2001). Finally, 10-fold serial dilutions of PCR products were performed for each gene to obtain standard curves ranging from $2 \times 10^{10}$ copies/ $\mu l$ to $2 \times 10^{2}$ copies/ $/$ l. These standard curves were used to test qPCR efficiency.

qPCR runs were performed to evaluate the efficiency of the primers and to observe the quality of the dilution of the PCR products using the established optimum concentration of each primer. The reaction was prepared with a final volume of $25 \mu \mathrm{l}$ with $0.5 \mu \mathrm{l}$ of PCR product template, $12.5 \mu \mathrm{l}$ of SYBR Green Supermix (Life Technologies), $0.5 \mu \mathrm{l}$ of $10 \mu \mathrm{M}$ primer set (for $200 \mathrm{nM}$ concentration) and $11.5 \mu \mathrm{l}$ of water molecular grade. All primers were tested in duplicate, along NTC. The qPCR runs were performed on a CFX96 Touch $^{\mathrm{TM}}$ Real-Time PCR Detection System (Bio-Rad) with the cycling protocol described earlier for optimization of primer concentration.

\section{Results and discussion}

\subsection{In silico and in vitro analyses performed with published primers}

The aim of in silico analyses was to investigate whether the published primers for the genes of interest allowed good amplification of specific sequences of target genes. The outcome of the in silico analyses performed with published primers for virulence genes are shown in Table 3. The in vitro tests were performed on those primers that presented the best characteristics desirable for qPCR. The results of in vitro analyses performed with the chosen primers are displayed in Fig. 1.

Previous studies on virulence gene expression have not described step wise primer optimization experiments (Alves et al., 2014; Chen and Lan, 2015; Dai et al., 2013; Green et al., 2004; Hnisz et al., 2012; Komalapriya et al., 2015; Martchenko et al., 2004; Naglik et al., 2003b; Nailis et al., 2010; Zhu et al., 2011). Most studies that evaluate virulence gene expression in C. albicans were performed using in vitro samples (Alves et al., 2014; Chen and Lan, 2015; Dai et al., 2013; Green et al., 2004; Hnisz et al., 2012; Komalapriya et al., 2015; Martchenko et al., 2004; Zhu et al., 2011) or were carried out with in vivo samples from animal models (Nailis et al., 2010), which allow greater control of the experimental conditions. On the other hand, in studies conducted with clinical samples, the great difficulty is the uncontrollability of these conditions. For clinical samples, it is necessary to use highly specific primers because different types of microorganisms can be found in the same specimen, making it difficult to obtain accurate gene expression data (i.e., absolute or relative quantification) of specific species with suboptimal primers.

In short, under the conditions employed here, as shown in Fig. 1A and B, the primers to detect the genes ACT1, HWP1, LIP3, PLB1, SAP1 and SAP4 described by Nailis et al. (2010) showed no specificity for $C$. albicans, because these primers resulted in PCR products for DNA from all Candida species evaluated, including the negative control (molecular grade water). The presence of amplicons in the negative control was double checked and can be the result of primer's poor characteristics. In Fig. 1C, the primer ACT1 described by Alves et al. (2014) resulted in 
Table 3

Outcome of in silico analyses of published primers.

\begin{tabular}{|c|c|c|c|c|}
\hline Gene & Primers (F: forward; R: reverse) & Advantages & Disadvantages & Reference \\
\hline \multirow[t]{3}{*}{ ACT1 } & $\begin{array}{l}\text { F - ACCACCGGTATTGTTTTGGA } \\
\text { R - AGCGTAAATTGGAACAACGTG }\end{array}$ & $\begin{array}{l}\text { - Appropriate CG\% for F (45\%) } \\
\text { and R ( } 42.9 \%) \\
\text { - GC Clamp on F and R ( } 2 \mathrm{kcal} / \\
\text { mol) }\end{array}$ & $\begin{array}{l}\text { - Sequence similarity with Candida spp. (F and R) } \\
\text { - Small product length }(60 \mathrm{bp}) \\
\text { - High Tm on F and R }\left(63.8^{\circ} \mathrm{C}\right) \\
\text { - Harpin on F }(-1.5 \mathrm{kcal} / \mathrm{mol}) \text { and R }(-1.9 \mathrm{kcal} / \mathrm{mol}) \\
\text { - Self Dimer on F }(-7.3 \mathrm{kcal} / \mathrm{mol}) \text { and } \mathrm{R}(-3.4 \mathrm{kcal} / \\
\text { mol) }\end{array}$ & $\begin{array}{l}\text { Komalapriya et al. } \\
\text { (2015) }\end{array}$ \\
\hline & $\begin{array}{l}\text { F: TTTCATCTTCTGTATCAGAGGAACTTATTT } \\
\text { R: ATGGGATGAATCATCAAACAAGAG }\end{array}$ & & $\begin{array}{l}\text { - These primers are not in the sequences of ACT1 -C. } \\
\text { albicans of Candida Genome Database and PubMed } \\
\text { - Sequence similarity with Candida spp. (F and R) } \\
\text { - Sequence similarity with DAD1 gene } \\
\text { - No sequence similarity with ACT1 } \\
\text { - Inappropriate GC\% on F }(30 \%) \text { and on R }(37.5 \%) \\
\text { - High Tm on F }\left(64.9^{\circ} \mathrm{C}\right) \text { and } \mathrm{R}\left(63.3^{\circ} \mathrm{C}\right) \\
\text { - Hairpins on F }(-2.5 \mathrm{kcal} / \mathrm{mol}) \text { and } \mathrm{R}(-2.2 \mathrm{kcal} / \\
\text { mol) } \\
\text { - Self Dimers on F }(-2.5 \mathrm{kcal} / \mathrm{mol}) \text { and R }(-3.5 \mathrm{kcal} / \\
\text { mol) } \\
\text { - GC Clamp on F and R }(3 \mathrm{kcal} / \mathrm{mol}) \\
\text { - Cross Dimer }(-4.7 \mathrm{kcal} / \mathrm{mol})\end{array}$ & Nailis et al. (2010) \\
\hline & $\begin{array}{l}\text { F - TGCTGAACGTATGCAAAAGG } \\
\text { R - TGAACAATGGATGGACCAGA }\end{array}$ & $\begin{array}{l}\text { - Appropriate product length } \\
\text { (186 bp) } \\
\text { - Appropriate CG\% for F and R } \\
\text { (45\%) } \\
\text { - No hairpin via Mfold analyses } \\
\text { - GC Clamp on F and R (2 kcal/ } \\
\text { mol) }\end{array}$ & $\begin{array}{l}\text { - Sequence similarity with Candida spp. (F and R) } \\
\text { - High Tm }\left(63^{\circ} \mathrm{C}\right) \\
\text { - Hairpin on F }(-2.0 \mathrm{kcal} / \mathrm{mol}) \text { and } \mathrm{R}(-1.5 \mathrm{kcal} / \\
\text { mol) } \\
\text { - Self Dimer on F }(-3.5 \mathrm{kcal} / \mathrm{mol}) \text { and on R } \\
\text { ( }-1.5 \mathrm{kcal} / \mathrm{mol}) \\
\text { - Cross Dimer }(-1.2 \mathrm{kcal} / \mathrm{mol})\end{array}$ & Alves et al. (2014) \\
\hline \multirow[t]{3}{*}{ ALS1 } & $\begin{array}{l}\text { F - CAAGTTACCTCATCCTCACCTTCA } \\
\text { R - GATAATAGAACCAGAGCCATCGTATG }\end{array}$ & $\begin{array}{l}\text { - Appropriate CG\% for F (45.8\%) } \\
\text { and R ( } 42.3 \%) \\
\text { - GC Clamp on F and R ( } 1 \mathrm{kcal} / \\
\text { mol) }\end{array}$ & $\begin{array}{l}\text { - Sequence similarity with Candida spp. (F and R) } \\
\text { - Small product length }(72 \mathrm{bp}) \\
\text { - High Tm for F }\left(66.1{ }^{\circ} \mathrm{C}\right) \text { an R }\left(65^{\circ} \mathrm{C}\right) \\
\text { - Harpin on F and R }(-0.6 \mathrm{kcal} / \mathrm{mol}) \\
\text { - Self Dimer on F and R }(-0.6 \mathrm{kcal} / \mathrm{mol}) \\
\text { - Cross Dimer }(-1.0 \mathrm{kcal} / \mathrm{mol}) \\
\text { - High sequence similarity with ALS3 via Clustal } \\
\text { analysis }\end{array}$ & $\begin{array}{l}\text { Chen and Lan } \\
\text { (2015) }\end{array}$ \\
\hline & $\begin{array}{l}\text { F - GACTAGTGAACCAACAAATACCAGA } \\
\text { R - CCAGAAGAAACAGCAGGTGA }\end{array}$ & $\begin{array}{l}\text { - No hairpins on F and } \mathrm{R} \\
\text { - Appropriate CG\% for F (40\%) } \\
\text { and R ( } 50 \%) \\
\text { - Few sequence similarity of F and } \\
\text { R with all of ALS genes via } \\
\text { Clustal analysis } \\
\text { - GC Clamp on F and R ( } 2 \mathrm{kcal} / \\
\text { mol) }\end{array}$ & $\begin{array}{l}\text { - Sequence similarity with Candida spp. (F and R) } \\
\text { - Big product length }(318 \mathrm{bp}) \\
\text { - High Tm for F }\left(64.7^{\circ} \mathrm{C}\right) \text { and } \mathrm{R}\left(64.1^{\circ} \mathrm{C}\right) \\
\text { - Self Dimer on F }(-4.6 \mathrm{kcal} / \mathrm{mol}) \\
\text { - Cross Dimer }(-1.5 \mathrm{kcal} / \mathrm{mol})\end{array}$ & Green et al. (2004) \\
\hline & $\begin{array}{l}\text { F - CCCAACTTGGAATGCTGTTT } \\
\text { R - TTTCAAAGCGTCGTTCACAG }\end{array}$ & $\begin{array}{l}\text { - Appropriate CG\% for F and R } \\
\text { (45\%) } \\
\text { - GC Clamp on F and R ( } 1 \mathrm{kcal} / \\
\text { mol) }\end{array}$ & $\begin{array}{l}\text { - Sequence similarity with Candida spp. (F and R) } \\
\text { - Big product length }(223 \mathrm{bp}) \\
\text { - High Tm for F }\left(63.2^{\circ} \mathrm{C}\right) \text { and } \mathrm{R}\left(63.4^{\circ} \mathrm{C}\right) \\
\text { - Self Dimer on } \mathrm{F}(-2.7 \mathrm{kcal} / \mathrm{mol}) \text { and } \mathrm{R}(-0.2 \mathrm{kcal} / \\
\text { mol) } \\
\text { - Cross Dimer }(-2.6 \mathrm{kcal} / \mathrm{mol}) \\
\text { - High sequence similarity with all of ALS genes via } \\
\text { Clustal analysis }\end{array}$ & Alves et al. (2014) \\
\hline \multirow[t]{2}{*}{ ALS3 } & $\begin{array}{l}\text { F - CTGCTCAAACAAATCCAAGTGTTC } \\
\text { R - CCATTTCCGTTGTTTCCTTTAGTAG }\end{array}$ & $\begin{array}{l}\text { - Appropriate CG\% for F (41.7\%) } \\
\text { and R ( } 40 \%) \\
\text { - GC Clamp on F and R ( } 2 \mathrm{kcal} / \\
\text { mol) }\end{array}$ & $\begin{array}{l}\text { - Sequence similarity with Candida spp. (F and R) } \\
\text { - Small product length }(76 \mathrm{bp}) \\
\text { - High Tm for F }\left(65.1^{\circ} \mathrm{C}\right) \text { and } \mathrm{R}\left(64.2^{\circ} \mathrm{C}\right) \\
\text { - Harpin on F }(-2.2 \mathrm{kcal} / \mathrm{mol}) \\
\text { - Self Dimer }(-4.5 \mathrm{kcal} / \mathrm{mol}) \\
\text { - High sequence similarity with ALS1 via Clustal } \\
\text { analysis }\end{array}$ & $\begin{array}{l}\text { Chen and Lan } \\
\text { (2015) }\end{array}$ \\
\hline & $\begin{array}{l}\text { F - CTGGACCACCAGGAAACACT } \\
\text { R - GGTGGAGCGGTGACAGTAGT }\end{array}$ & $\begin{array}{l}\text { - Appropriate CG\% for F (55\%) } \\
\text { and R (60\%) } \\
\text { - GC Clamp on F ( } 1 \mathrm{kcal} / \mathrm{mol}) \text { and } \\
\text { R ( } 2 \mathrm{kcal} / \mathrm{mol})\end{array}$ & $\begin{array}{l}\text { - Sequence similarity with Candida spp. (F and R) } \\
\text { - High sequence similarity with all ALS via Clustal } \\
\text { analysis } \\
\text { - Big PCR product length }(226 \mathrm{bp}) \\
\text { - High Tm for F }\left(66^{\circ} \mathrm{C}\right) \text { and } \mathrm{R}\left(67.9^{\circ} \mathrm{C}\right) \\
\text { - Harpin on F }(-3.1 \mathrm{kcal} / \mathrm{mol}) \\
\text { - Self Dimer }(-5.2 \mathrm{kcal} / \mathrm{mol})\end{array}$ & Alves et al. (2014) \\
\hline CAP1 & $\begin{array}{l}\text { F- ACCTGAAAAACAAGAGAAAGGTAAAT } \\
\text { R - GGTGGAGCGGTGACAGTAGT }\end{array}$ & $\begin{array}{l}\text { - Appropriate product length } \\
\text { ( } 96 \mathrm{bp)} \\
\text { - Appropriate CG\% on R (55.6\%) }\end{array}$ & $\begin{array}{l}\text { - Sequence similarity with Candida spp. (F and R) } \\
\text { - High Tm for F }\left(63.6{ }^{\circ} \mathrm{C}\right) \text { and } \mathrm{R}\left(64.6^{\circ} \mathrm{C}\right) \\
\text { - Inappropriate GC } \% \text { for F }(30.8 \%) \\
\text { - Hairpin on F }(-2.8 \mathrm{kcal} / \mathrm{mol}) \\
\text { - Self Dimer on F }(-2.8 \mathrm{kcal} / \mathrm{mol}) \text { and R }(-9.2 \mathrm{kcal} / \\
\text { mol) } \\
\text { - Cross Dimer }(-2.1 \mathrm{kcal} / \mathrm{mol})\end{array}$ & $\begin{array}{l}\text { Komalapriya et al. } \\
\text { (2015) }\end{array}$ \\
\hline & $\begin{array}{l}\text { F - ACCGTGAACGTAAAGAACG } \\
\text { R - GCTACCACCAGTATATTTAGCC }\end{array}$ & $\begin{array}{l}\text { - Appropriate product length } \\
\text { (152 bp) }\end{array}$ & $\begin{array}{l}\text { - Sequence similarity with Candida spp. (F and R) } \\
\text { - High Tm for F and R }\left(62.2^{\circ} \mathrm{C}\right) \\
\text { - GC Clamp on R ( } 3 \mathrm{kcal} / \mathrm{mol})\end{array}$ & Dai et al. (2013) \\
\hline
\end{tabular}


Table 3 (continued)

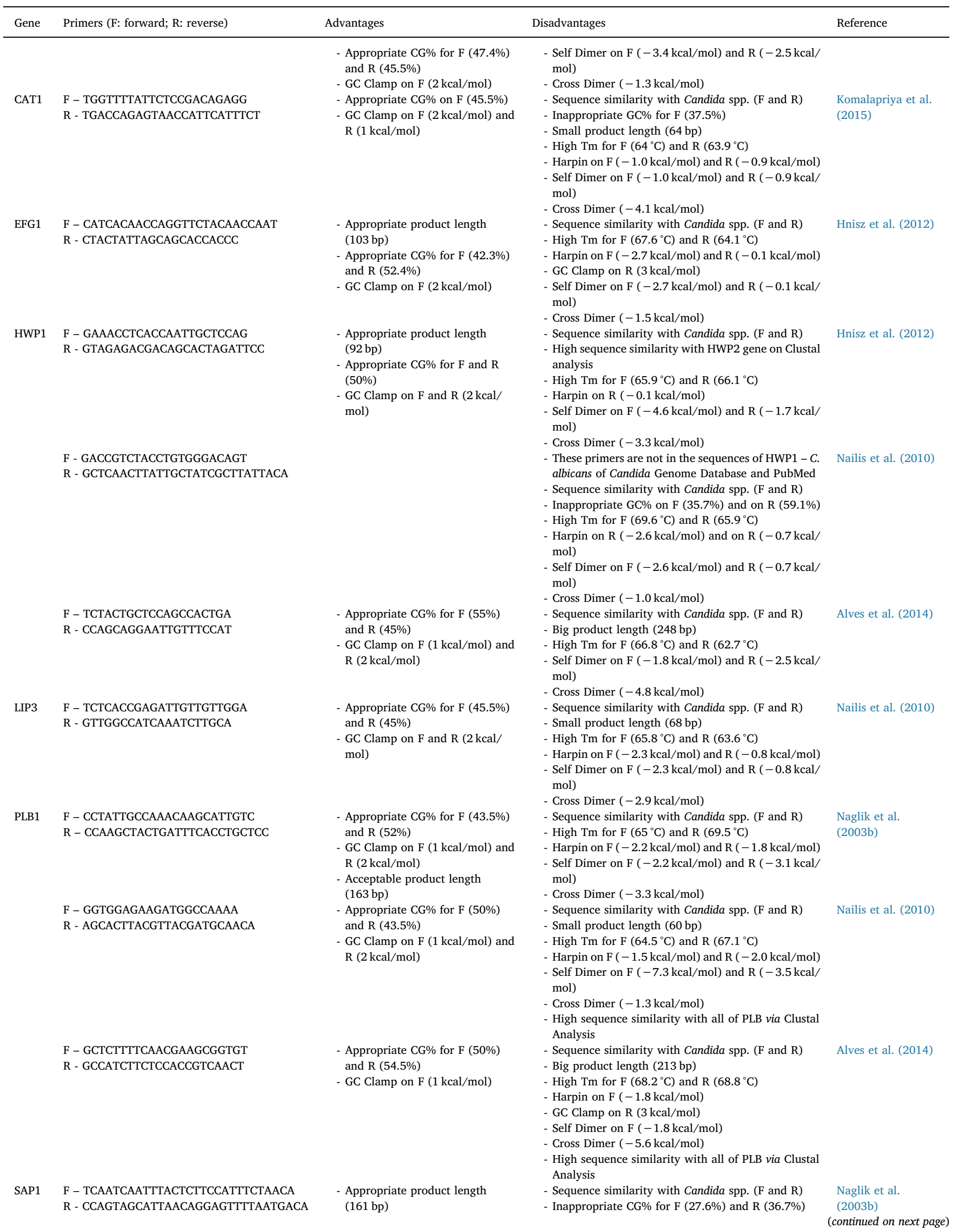


Table 3 (continued)

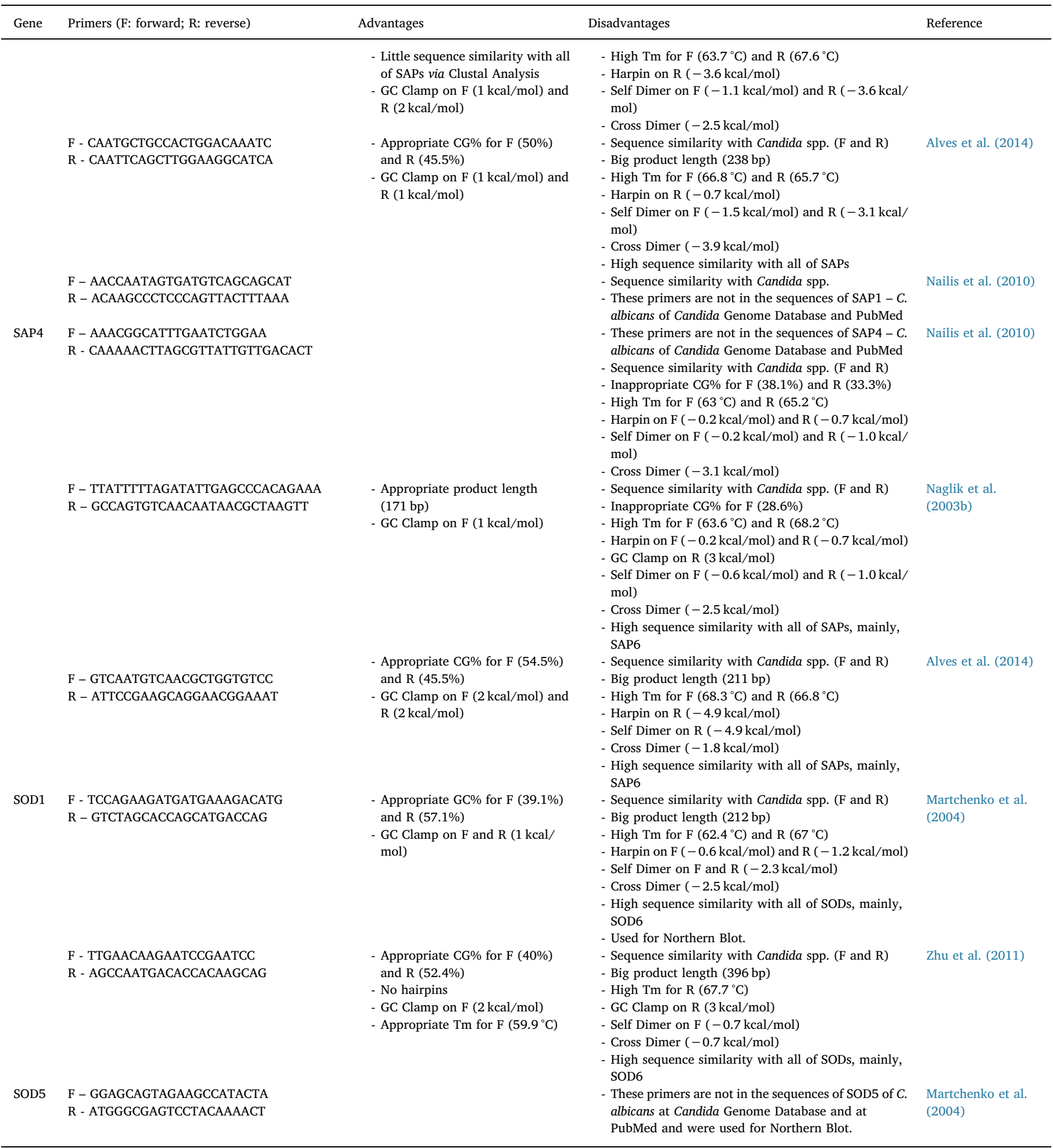



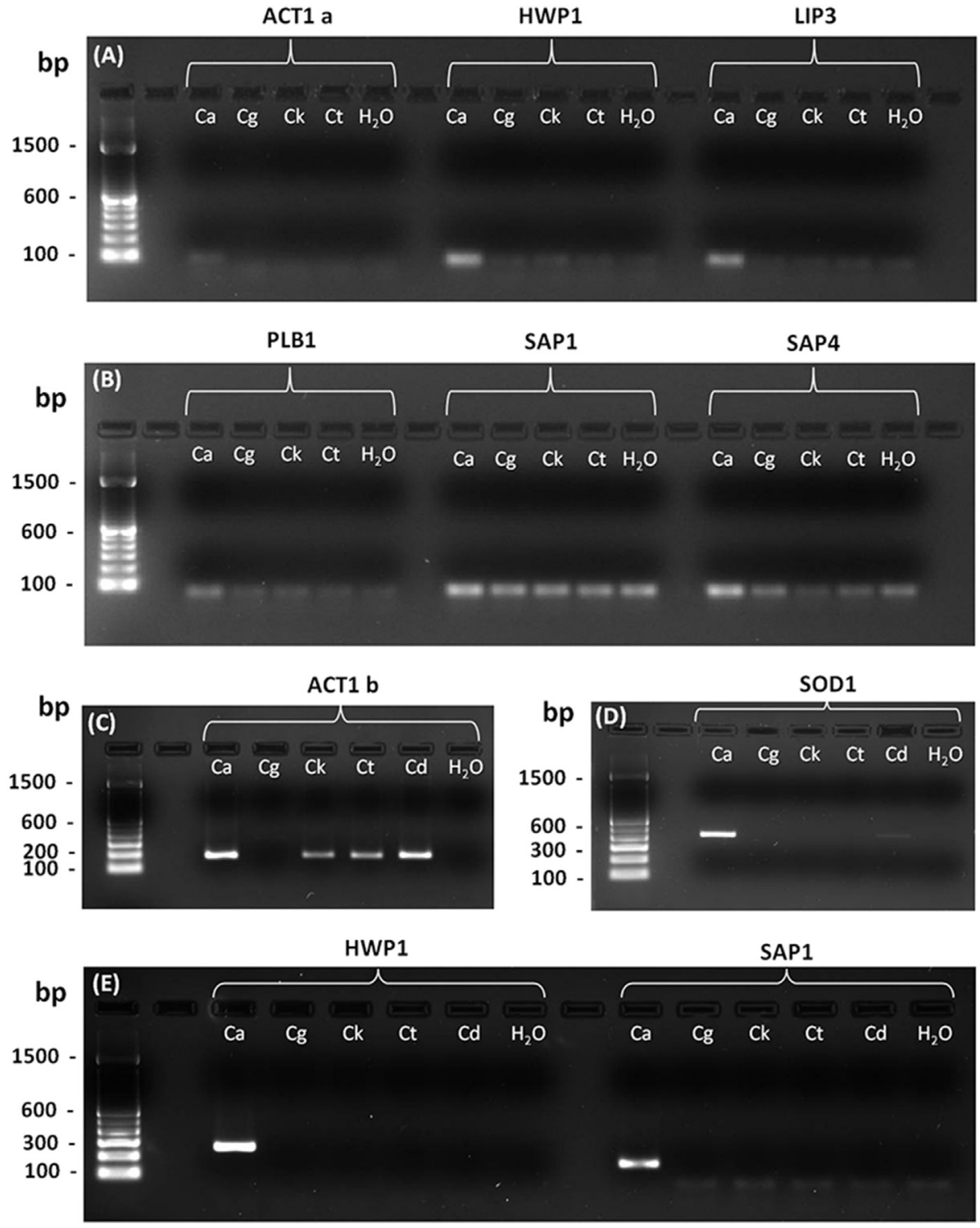

Fig. 1. Amplification of selected C. albicans virulence genes using published primers. In A and B, the images show a lack of specificity of the primers pairs for the genes ACT1 a, HWP1, LIP3, PLB1, SAP1 and SAP4 described by Nailis et al. (2010) in Candida species. In C, the images show a lack of specificity of the primer pair for the gene ACT1 b described by Alves et al. (2014) in Candida species. In D, the detection on C. albicans and C. dubliniensis of primer for the gene SOD1 described by Zhu et al. (2011). The low intensity of the band of the primer for SOD1 on $C$. $d u$ bliniensis, does not disqualify the detection of this primer in this species. In E the image shows specificity of the primer pair for C. albicans for the gene HWP1 described by Alves et al. (2014) and for the gene SAP1 described by Naglik et al. (2003b) (Ca: Candida albicans, Cg: Candida glabrata, Ck: Candida krusei, Ct: Candida tropicalis, C. dubliniensis, $\mathrm{H}_{2} \mathrm{O}$ : molecular grade water). The suppliers used on these experiments were distinct from the revised papers. Images acquired after agarose gel electrophoresis by a Gel Doc XR + System equipment via Image Lab Software. amplicons for C. albicans, C. krusei, C. tropicalis and C. dubliniensis. In the Fig. 1E, the primer for SAP1 from Naglik et al. (2003b), showed specificity for C. albicans as the primer for HWP1 gene from Alves et al. (2014). The primer for SOD1 gene (Zhu et al., 2011) showed a band for C. dubliniensis (Fig. 1D).

In the study conducted by Nailis et al. (2010), the authors mentioned that the specificity of the primers were checked by Blast and it was observed absence of cross reaction with other organisms, efficiency of primers between 90 and $110 \%$, and absence of secondary structures. In contrast, when the primers for genes ACT1, SAP1, SAP4, PLB1, LIP3 and HWP1 were subject to in silico analyses in the present study, the output demonstrated not only satisfactory characteristics, but poor ones (Table 3). In addition, the primer sequences of ACT1, HWP1, SAP1 and SAP4 were not found in the gene sequences obtained from the Candida Genome Database and NCBI entries. Moreover, the in vitro tests demonstrated that the primers for the genes ACT1, HWP1, LIP3, PLB1, SAP1 and SAP4 (Nailis et al., 2010) showed cross reaction with other Candida spp. (Fig. 1A-B), including amplicons for the negative control (molecular grade water). The PCR products in the negative controls can be explained by the presence of secondary structures in the primers (showed on in silico analysis in Table 3), which allow inter and intramolecular bonds that result in nonspecific products. Cross-reactivity with different Candida spp. was also confirmed by in silico analysis via
BLAST and ClustalW2 (Table 3). Therefore, these primers cannot be used to study clinical samples from patients.

The primers described by Nailis et al. (2010) were utilized in an in vitro study conducted by Seleem et al. (2016). They observed that the expression of SAP1, PLB1 and ACT1, after a novel therapy against candidosis, did not show statistical difference when compared with the control. In light of our results, perhaps these studies may have yielded some non-specific products. After in silico analyses of primers described by Alves et al. (2014) (ACT1, ALS1, ALS3, HWP1, PLB1, SAP1 and SAP4), the primers for ACT1 and HWP1 genes showed good characteristics (Table 3). It was observed in in vitro analyses that the primer for C. albicans ACT1 exhibited cross reaction with C. krusei, C. tropicalis and C. dubliniensis (Fig. 1C). On the other hand, the primer pair for HWP1, showed specificity for $C$. albicans and can be used for in vivo studies (Fig. 1E).

Although the SAP1 primer pair (Naglik et al., 2003b) yielded a large amplicon (161 bp) (i.e., primer length) when compared with the ideal (80-150 bp), it is acceptable and was chosen for in vitro analyses in the present study because the authors described its specificity to analyze clinical samples of patients with oral and vaginal candidiasis lesions (Naglik et al., 2003b). In the in vitro test, it was observed that the primers for SAP1 showed specificity for C. albicans (Fig. 1E), but, the primers for SAP4 (Naglik et al., 2003b) did not show good characteristic 
Table 4

In silico analyses of newly designed primers.

\begin{tabular}{|c|c|c|c|}
\hline Gene & Primers (F: forward; R: reverse) & Advantages & Disadvantages \\
\hline ACT1 & $\begin{array}{l}\text { F - ATTCGGTGAGTAATCCTA } \\
\text { R - GTATAGTCCAGATAACAACA }\end{array}$ & $\begin{array}{l}\text { - Appropriate product length (167 bp) } \\
\text { - Appropriate primer length (F: } 18 \text { bp and R: } 20 \mathrm{bp}) \\
\text { - Appropriate } \mathrm{CG} \% \text { for } \mathrm{F}(38.9 \%) \text { and } \mathrm{R}(35 \%) \\
\text { - Appropriate } \mathrm{Tm} \text { for } \mathrm{R}\left(55.5^{\circ} \mathrm{C}\right) \text { and } \mathrm{F}\left(55.5^{\circ} \mathrm{C}\right) \\
\text { - GC Clamp on } \mathrm{F}(2) \text { and } \mathrm{R}(1)\end{array}$ & $\begin{array}{l}\text { - Sequence similarity with Candida spp. (F and R) } \\
\text { - Self Dimer on R }(-0.3 \mathrm{kcal} / \mathrm{mol}) \\
\text { - Cross Dimer }(-0.4 \mathrm{kcal} / \mathrm{mol}) \\
\text { - Small hairpin on Forward (Mfold) }\end{array}$ \\
\hline ALS1 & $\begin{array}{l}\text { F - CATCATTGACTCAGTTGT } \\
\text { R - CAGTGGAAGTAGATTGTG }\end{array}$ & $\begin{array}{l}\text { - Appropriate product length (117 bp) } \\
\text { - Appropriate primer length (F and R: } 18 \mathrm{bp}) \\
\text { - Appropriate CG\% for F }(38.9 \%) \text { and } \mathrm{R}(44.4 \%) \\
\text { - Appropriate } \mathrm{Tm} \text { for R }\left(55.9^{\circ} \mathrm{C}\right) \text { and } \mathrm{F}\left(56^{\circ} \mathrm{C}\right) \\
\text { - GC Clamp on F and R }(1) \\
\text { - No hairpins } \\
\text { - Little sequence similarity with all of ALSs via Clustal Analysis }\end{array}$ & $\begin{array}{l}\text { - Sequence similarity with Candida spp. (F and R) } \\
\text { - Self Dimer on F }(-0.9 \mathrm{kcal} / \mathrm{mol}) \\
\text { - Cross Dimer ( }-0.9 \mathrm{kcal} / \mathrm{mol})\end{array}$ \\
\hline CAP1 & $\begin{array}{l}\text { F - AGTCAATTCAATGTTCAAG } \\
\text { R - AATGGTAATGTCCTCAAG }\end{array}$ & $\begin{array}{l}\text { - Appropriate product length ( } 87 \mathrm{bp}) \\
\text { - Appropriate primer length (F: } 19 \mathrm{bp} \text { and R: } 18 \mathrm{bp}) \\
\text { - Appropriate CG\% for F }(31.6 \%) \text { and R }(38.9 \%) \\
\text { - Appropriate } \mathrm{Tm} \text { for R }\left(55^{\circ} \mathrm{C}\right) \text { and } \mathrm{F}\left(55.2^{\circ} \mathrm{C}\right) \\
\text { - GC Clamp on F and R (1) } \\
\text { - No hairpins } \\
\text { - No Cross Dimer }\end{array}$ & $\begin{array}{l}\text { - Sequence similarity with Candida spp. (F and R) } \\
\text { - Self Dimer on F ( }-1.1 \mathrm{kcal} / \mathrm{mol})\end{array}$ \\
\hline CAT1 & $\begin{array}{l}\text { F - GACTGCTTACATTCAAAC } \\
\text { R - AACTTACCAAATCTTCTCA }\end{array}$ & $\begin{array}{l}\text { - Appropriate product length (117 bp) } \\
\text { - Appropriate primer length (F: } 18 \text { bp and R: } 19 \mathrm{bp}) \\
\text { - Appropriate CG\% for F }(38.9 \%) \text { and R }(31.6 \%) \\
\text { - Appropriate Tm for R and F }\left(55.1^{\circ} \mathrm{C}\right) \\
\text { - GC Clamp on F and R (1) } \\
\text { - No hairpins } \\
\text { - No Cross Dimer } \\
\text { - No Self Dimer }\end{array}$ & - Sequence similarity with Candida spp. (F and R) \\
\hline EFG1 & $\begin{array}{l}\text { F - ACGAGTAACAACTACCAT } \\
\text { R - TATCTGCTCTTCTGACAA }\end{array}$ & $\begin{array}{l}\text { - Appropriate product length ( } 89 \mathrm{bp}) \\
\text { - Appropriate primer length }(\mathrm{F} \text { and } \mathrm{R}: 18 \mathrm{bp}) \\
\text { - Appropriate CG\% for F and R }(38.9 \%) \\
\text { - Appropriate Tm for F }\left(56.5^{\circ} \mathrm{C}\right) \text { and } \mathrm{R}\left(56.2^{\circ} \mathrm{C}\right) \\
\text { - GC Clamp on F (2) and R (1) }\end{array}$ & $\begin{array}{l}\text { - Sequence similarity with Candida spp. (F and R) } \\
\text { - Hairpin on F }(-0.9 \mathrm{kcal} / \mathrm{mol}) \\
\text { - Self Dimer on F }(-0.9 \mathrm{kcal} / \mathrm{mol}) \\
\text { - Cross Dimer }(-1 \mathrm{kcal} / \mathrm{mol})\end{array}$ \\
\hline HWP1 & $\begin{array}{l}\text { F - CTCCAAAATCATCAGCTC } \\
\text { R - CACTAGCCAAAACAGAAG }\end{array}$ & $\begin{array}{l}\text { - Appropriate product length (114 bp) } \\
\text { - Appropriate primer length for } \mathrm{F} \text { and } \mathrm{R}(18 \mathrm{bp}) \\
\text { - Appropriate } \mathrm{CG} \% \text { for } \mathrm{F} \text { and } \mathrm{R}(44.4 \%) \\
\text { - Appropriate } \mathrm{Tm} \text { for } \mathrm{F}\left(56.8^{\circ} \mathrm{C}\right) \text { and } \mathrm{R}\left(57^{\circ} \mathrm{C}\right) \\
\text { - GC Clamp on F (2) and R (1) }\end{array}$ & $\begin{array}{l}\text { - Sequence similarity with Candida spp. (F and R) } \\
\text { - Self Dimer on F }(-3.1 \mathrm{kcal} / \mathrm{mol}) \text { and R }(-1.7 \mathrm{kcal} / \mathrm{mol}) \\
\text { - Cross Dimer ( }-1.8 \mathrm{kcal} / \mathrm{mol}) \\
\text { - Hairpin on R (Mfold) }\end{array}$ \\
\hline LIP3 & $\begin{array}{l}\text { F - AGAGAATGTATGAAGTTGT } \\
\text { R - CCCTGTTCAAAGTATCTAT }\end{array}$ & $\begin{array}{l}\text { - Appropriate product length ( } 136 \mathrm{bp}) \\
\text { - Appropriate primer length for F and R (19bp) } \\
\text { - Appropriate CG\% for F }(31.6 \%) \text { and R }(36.8 \%) \\
\text { - Appropriate Tm for F }\left(54.9^{\circ} \mathrm{C}\right) \text { and R }\left(55^{\circ} \mathrm{C}\right) \\
\text { - No hairpins } \\
\text { - No Self Dimer } \\
\text { - GC Clamp on F and R (1) }\end{array}$ & $\begin{array}{l}\text { - Sequence similarity with Candida spp. (F and R) } \\
\text { - High sequence similarity with all of LIPs via Clustal Analysis } \\
\text { - Cross Dimer }(-2.1 \mathrm{kcal} / \mathrm{mol})\end{array}$ \\
\hline PLB1 & $\begin{array}{l}\text { F - GGCATTGAACATCCTATA } \\
\text { R - GGTAACTTAATAGTCTTCCA }\end{array}$ & $\begin{array}{l}\text { - Appropriate product length (124bp) } \\
\text { - Appropriate primer length for F (18 bp) and R (20 bp) } \\
\text { - Appropriate CG\% for F }(38.9 \%) \text { and } \mathrm{R}(35 \%) \\
\text { - Appropriate } \mathrm{Tm} \text { for } \mathrm{F}\left(55^{\circ} \mathrm{C}\right) \text { and } \mathrm{R}\left(55.4^{\circ} \mathrm{C}\right) \\
\text { - GC Clamp on } \mathrm{F} \text { and } \mathrm{R}(1)\end{array}$ & $\begin{array}{l}\text { - Sequence similarity with Candida spp. (F and R) } \\
\text { - High sequence similarity with all of PLBs on Clustal Analysis } \\
\text { - Cross Dimer }(-1.1 \mathrm{kcal} / \mathrm{mol}) \\
\text { - Hairpin on R }(-0.9 \mathrm{kcal} / \mathrm{mol}) \\
\text { - Self Dimer on F }(-0.3 \mathrm{kcal} / \mathrm{mol}) \text { and R }(-0.9 \mathrm{kcal} / \mathrm{mol})\end{array}$ \\
\hline
\end{tabular}

in silico. High sequence similarity was observed among SAPs gene sequences. The primers described for PLB1 also did not show good characteristics in silico (Table 3) and was not tested further.

Here, the SOD1 primer pair (Zhu et al., 2011) reacted with DNA from $C$. albicans and cross-reacted with DNA from $C$. dubliniensis. It probably occurred because these species are closely related (Jackson et al., 2009; Moran et al., 2012; Sullivan et al., 2005) and it is difficult to discern them in clinical samples (Gilfillan et al., 1998; McManus et al., 2008). C. albicans and C. dubliniensis share many phenotypic characteristics, including the ability to produce hyphae and chlamydospores (Gilfillan et al., 1998; Jackson et al., 2009; McManus et al., 2008; Moran et al., 2012) making it difficult to find specific primers for C. albicans.

\subsection{In silico and in vitro analyses performed with newly designed primer}

New primers were designed using the Beacon Designer ${ }^{\mathrm{TM}}$ for genes that did not have suitable primers identified in literature after in silico and in vitro analyses. According to Nolan et al. (2006) the Beacon
Designer $^{\mathrm{TM}}$ is the most comprehensive commercial program. The new primers were designed using Beacon following the characteristics described by Bustin (2004) and Thornton and Basu (2011).

The newly designed primers were submitted to in silico analyses (Blastn, Clustal and Mfold) and all of them exhibited high sequence similarity with Candida spp. (Table 4). Again, these results can be attributed to the high similarity between the Candida spp. genomes. For example, about $85 \%$ of the genes originally identified in C. albicans, have homologs in non-albicans Candida spp. (Thompson et al., 2011), including the filamentous-growth transcriptional genes. This may explain the difficulty to find specific primers for $C$. albicans without crossreaction with the other Candida species. In addition, it was observed that the designed primers showed primer length between 18 and $24 \mathrm{bp}$ and GC content around 50\% (Table 4). It is important because these features contribute to a higher yield of PCR product (Nolan et al., 2006).

Despite the high sequence similarity among Candida spp., C. albicans shows a distantly related genome when compared with the emerging multidrug resistance fungus $C$. auris; however, these two species share 

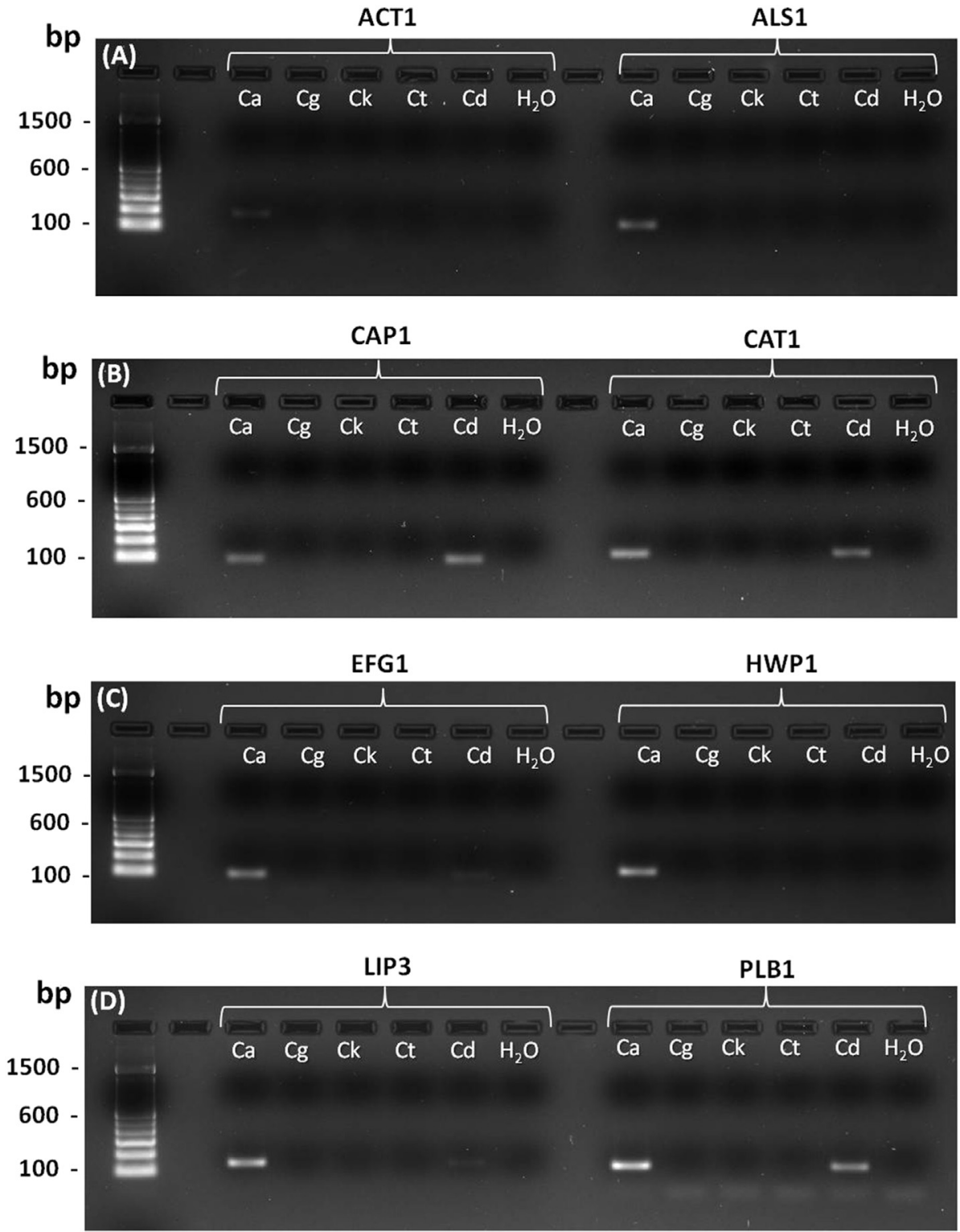

Fig. 2. Agarose gels showing PCR products from newly designed primers. In A, the images show specificity to $C$. albicans of the primers pairs for the genes ACT1 and ALS1. In $\mathrm{B}$, the primers for the genes CAP1 and CAT1 showed detection in C. albicans and C. dubliniensis. In C, detection of the primer for EFG1 gene in C. albicans and C. dubliniensis and the specificity to C. albicans for the gene HWP1. In D, the primers for the gene LIP3 and PLB1 showed detection in C. albicans and C. dubliniensis (Ca: Candida albicans, Cg: Candida glabrata, Ck: Candida krusei, Ct: Candida tropicalis, Cd: Candida dubliniensis, $\mathrm{H}_{2} \mathrm{O}$ : molecular grade water). Images acquired after agarose gel electrophoresis by a $\mathrm{Gel}$ Doc XR+ System equipment via Image Lab Software. common virulence factors (Chatterjee et al., 2015). All the selected specific primers for $C$. albicans in this study presented no sequence similarity with $C$. auris through in silico analyses.

The in vitro experiments using end point PCR demonstrated that primers for ACT1, ALS1 and HWP1 showed specificity for C. albicans (Fig. 2A and C) whereas the primers for LIP3, CAP1, CAT1, EFG1 and PLB1 yielded amplicons for C. albicans and C. dubliniensis (Fig. 2B, C and D) similarly to the cross-reaction with $C$. albicans and $C$. dubliniensis found for the gene SOD1 of published primers (Fig. 1D). As previously mentioned, C. dubliniensis is phenotypically, genetically, and phylogenetically most closely related to C. albicans (Gilfillan et al., 1998; McManus et al., 2008), thus both species present high sequence similarity. As described by Jackson et al. (2009), of the 5569 orthologous genes, $44.4 \%$ are more than $90 \%$ identical at the nucleotide level and $96.3 \%$ are more than $80 \%$ identical, with $98.1 \%$ of all C. dubliniensis putative genes preserve in $C$. albicans and $C$. dubliniensis. These primers can be used in studies with clinical samples from patients with candidosis because, despite of the similarity and difficulty to find specific primers, these species differs on pathogenicity and frequency, where, $C$. albicans is often more prevalent (Moran et al., 2012).

\subsection{Selected primers for optimization of $q P C R$ reactions}

The primers chosen for further optimization were those for: ACT1, HWP1, ALS1, LIP3, CAT1, CAP1, EFG1 and PLB1 (designed by Beacon Designer $^{\mathrm{Tm}}$ ), HWP1 (Alves et al., 2014), SAP1 (Naglik et al., 2003b), and SOD1 (Zhu et al., 2011). No suitable primers were found for ALS3, SOD5 and SAP4, because of the high sequence similarity between the species and genes of the same family (data from literature shown in Table 3).

Next, the selected primers for ACT1, ALS1, CAP1, CAT1, EFG1, HWP1, LIP3, PLB1, SAP1, and SOD1 were tested to evaluate optimal concentration via $\mathrm{qPCR}$ (the optimal concentration that yielded the lowest Cq on the amplification plot in Fig. 3). The optimal concentration of each primer and the annealing temperature for the reaction are presented in Table 5.

According to Thornton and Basu (2011), the ideal Tm should be close to $59 / 60^{\circ} \mathrm{C}$. On the other hand, Bustin (2004) described an ideal $\mathrm{Tm}$ of $55^{\circ} \mathrm{C}$ because the Tm of a DNA molecule depends of the size and composition of nucleotides, thus GC-rich amplicons have a higher Tm than those have more AT base pairs (Nolan et al., 2006). The quality control for a primer design was described as essential by Nolan et al. 
(A)

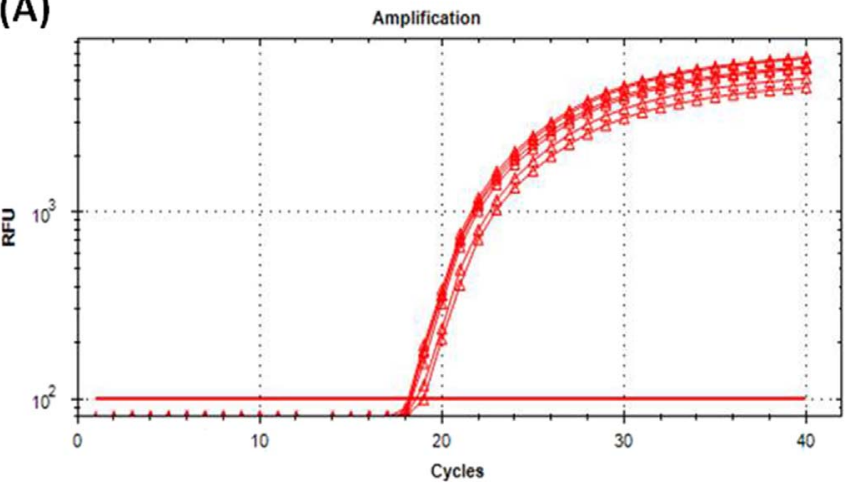

(B)

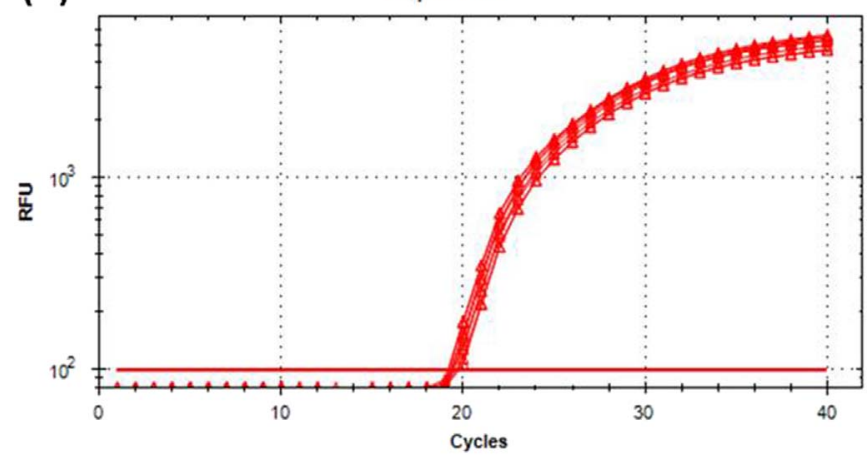

Fig. 3. Amplification plot graphs. Graphs obtained during the determination of the optimal concentration of the primers LIP3 (A) and ACT1 (B). The optimal concentration is considered the one with the lowest Cq. Image A is the graph obtained for the LIP3 gene, for which the optimal concentration is $350 \mathrm{nM}$. The mean values of Cq obtained were: 19.83 for $200 \mathrm{nM}$; 19.56 to $250 \mathrm{nM}$; 19.35 for $300 \mathrm{nM}$; and 19.15 to $350 \mathrm{nM}$. Image B is the graph obtained for the ACT1 gene, which presented optimal concentration of $300 \mathrm{nM}$. The mean values of Cq obtained were: 18.86 for $200 \mathrm{nM}$; 18.24 for $250 \mathrm{nM}$; 18.15 for $300 \mathrm{nM}$. Note: For those primers tested where Cq values were close at different primer concentrations, the concentrations chosen were those with the lowest value. Images generated by Bio-Rad CFX Manager ${ }^{\mathrm{TM}}$ Software.
(2006), which presented as the most important parameters: highest efficiency and sensitivity of primers and the absence of primer dimers. The primers for this study were analyzed for these important parameters. Moreover, the qPCR detection limits were: $10 \mathrm{pg} / \mu \mathrm{l}$ for ACT1, $0.5 \mathrm{pg} / \mu \mathrm{l}$ for primers ASL1, CAP1, CAT1, EFG1, HWP1, PBL1 SAP1, SOD1, while $50 \mathrm{fg} / \mu 1$ for primer LIP3.

For all the selected primers, the QPCR standard curves were made from the serial dilution of purified PCR products and resulted in $90-110 \%$ efficiency and $R=0.99$, with slope of $\cong-3.3$ (Fig. 4). The amplification plots showed equidistant dilutions points and the melting curve showed a single peak. As described by Nolan et al. (2006) the melt curve analysis is a powerful tool that provides an accurate identification of amplified products, distinguishing them of unspecific products (artefacts) and primer dimers.

Understanding the virulence and the resistance mechanisms associated with Candida spp. is clearly important. The increasing incidence of superficial and systemic infections caused by these fungi has been attributed to resistance and to the expression of many virulence factors present after exposure to antifungal treatments. Knowledge about the expression of virulence genes and how therapeutic approaches affect the expression of those genes can be an indicator of treatment/intervention effectiveness.

Nevertheless, if for example one wants to evaluate the expression of Secreted Aspartyl Proteinases or SAPs, independently of other Candida species or even SAP family genes, having a primer set that amplifies efficiently all available sequences would tell whether this specific virulence trait of Candida species is being modified or not after a specific therapeutic approach, without discriminating the specific gene or species. If one wishes to use this general approach, some of the primers tested in silico here did demonstrated that they are non-specific (ALS3, SOD5 and SAP4) and can be used to get an overall expression profile.

In summary, eight newly designed primers (ACT1, HWP1, ALS1, LIP3, CAT1, CAP1, EFG1 and PLB1) and three published primers (HWP1 by Alves et al., 2014, SAP1 by Naglik et al., 2003b, and SOD1 by Zhu et al., 2011) were standardized and under the conditions described, are suitable for use in clinical studies. Such studies could address whether the expression of $C$. albicans virulence genes is implicated in the pathogenic potential of biofilms or whether these genes are affected by therapeutic interventions. The standardization of $C$. albicans specific primers, not described stepwise previously, affects positively the amplification efficiency. The results demonstrate that these primers should

Table 5

$\mathrm{Tm}$, secondary structures and optimal concentration of the primers.

\begin{tabular}{|c|c|c|c|c|c|c|}
\hline Gene & Primers & $\operatorname{Tm}\left({ }^{\circ} \mathrm{C}\right)$ & Product $\operatorname{Tm}\left({ }^{\circ} \mathrm{C}\right)$ & Product secondary structure ${ }^{a}$ & Optimal concentration (nM) & Reference \\
\hline ACT1 & $\begin{array}{l}\text { F - ATTCGGTGAGTAATCCTA } \\
\text { R - GTATAGTCCAGATAACAACA }\end{array}$ & 55 & 75.3 & -0.4 & 350 & This study (Beacon) \\
\hline ALS1 & $\begin{array}{l}\text { F - CATCATTGACTCAGTTGT } \\
\text { R - CAGTGGAAGTAGATTGTG }\end{array}$ & & 74.2 & -0.9 & 300 & \\
\hline CAP1 & $\begin{array}{l}\text { F - AGTCAATTCAATGTTCAAG } \\
\text { R - AATGGTAATGTCCTCAAG }\end{array}$ & 50 & 71.8 & 0.0 & 400 & \\
\hline CAT1 & $\begin{array}{l}\text { F - GACTGCTTACATTCAAAC } \\
\text { R - AACTTACCAAATCTTCTCA }\end{array}$ & & 74.9 & 0.0 & 350 & \\
\hline EFG1 & $\begin{array}{l}\text { F - ACGAGTAACAACTACCAT } \\
\text { R - TATCTGCTCTTCTGACAA }\end{array}$ & & 73.4 & -1.0 & & \\
\hline HWP1 & $\begin{array}{l}\text { F - CTCCAAAATCATCAGCTC } \\
\text { R - CACTAGCCAAAACAGAAG }\end{array}$ & 55 & 79.5 & -1.8 & 300 & \\
\hline & $\begin{array}{l}\text { F - TCTACTGCTCCAGCCACTGA } \\
\text { R - CCAGCAGGAATTGTTTCCAT }\end{array}$ & 60 & 79.2 & -4.8 & 450 & Alves et al. (2014) \\
\hline LIP3 & $\begin{array}{l}\text { F - AGAGAATGTATGAAGTTGT } \\
\text { R - CCCTGTTCAAAGTATCTAT }\end{array}$ & 55 & 76.2 & -2.1 & 300 & This study (Beacon) \\
\hline PLB1 & $\begin{array}{l}\text { F - GGCATTGAACATCCTATA } \\
\text { R - GGTAACTTAATAGTCTTCCA }\end{array}$ & & 73.0 & $-1,1$ & & \\
\hline SAP1 & $\begin{array}{l}\text { F - TCAATCAATTTACTCTTCCATTTCTAACA } \\
\text { R - CCAGTAGCATTAACAGGAGTTTTAATGACA }\end{array}$ & 60 & 74.2 & -2.5 & 600 & Naglik et al. (2003b) \\
\hline SOD1 & $\begin{array}{l}\text { F - TTGAACAAGAATCCGAATCC } \\
\text { R - AGCCAATGACACCACAAGCAG }\end{array}$ & & 78.7 & -0.7 & 400 & Zhu et al. (2011) \\
\hline
\end{tabular}

${ }^{\text {a }}$ Cross Dimer $\Delta \mathrm{G}(\mathrm{kcal} / \mathrm{mol})$ from Beacon Designer. 


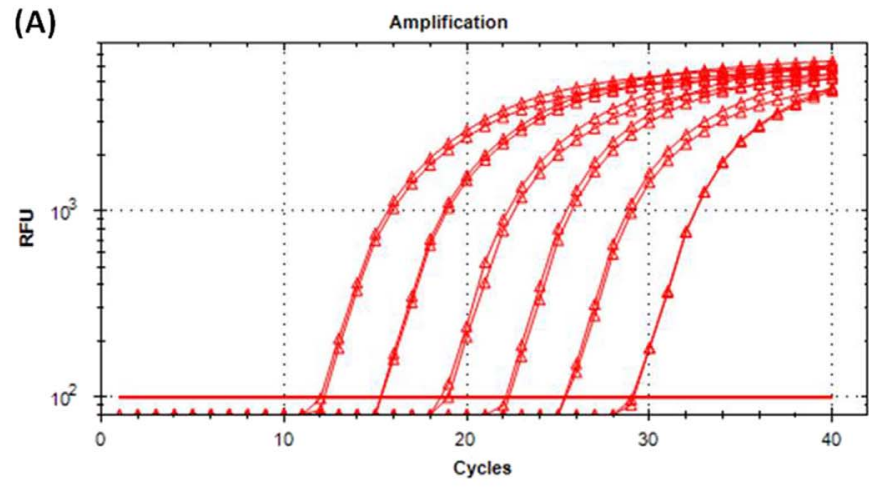

(B)

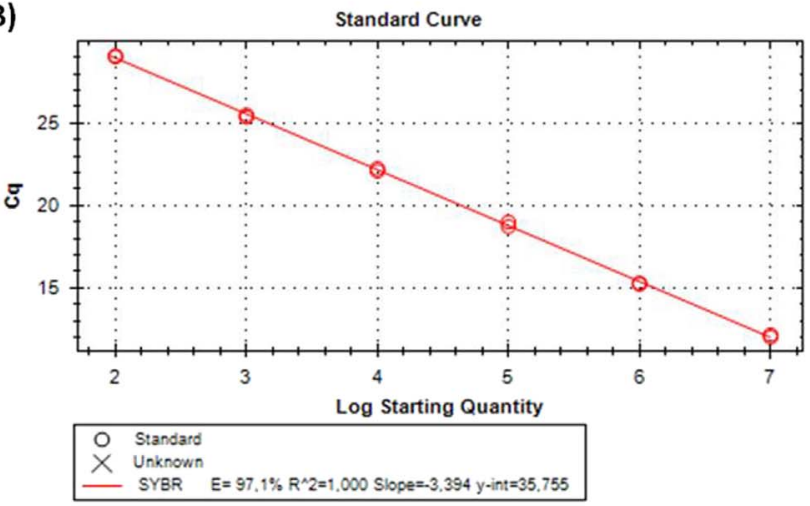

(C)

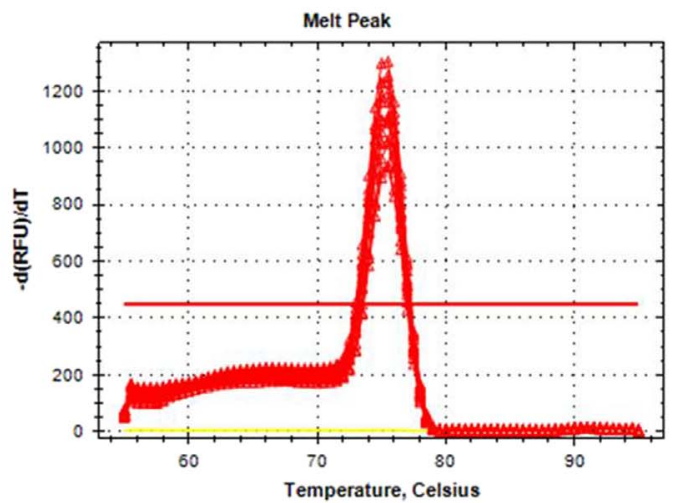

Fig. 4. Amplification plot, standard curve and melt curve graphs. Graphs obtained for standard curve based on PCR product of primer for ALS1 gene. Panel A, shows an example of an amplification plot. The red lines show the PCR products equidistant points in the amplification curve. The NTC (yellow lines) was not detected. Panel B depicts the standard curve graph, with the dilution points and values for efficiency (E), correlation coefficient $\mathrm{R}$ and slope. The standard curve for ALS1 showed adequate parameters $(\mathrm{E}=97.1 \%, \mathrm{R}=1.000$, slope $=-3394)$ and similar outcomes were observed for all genes tested. Panel C, it's observed the melt peak. The presence of one peak shows the detection of a single product. It is observed that Images generated by Bio-Rad CFX Manager $^{\mathrm{TM}}$ Software.

be suitable for gene expression analyses in experiments with clinical samples to determine, for example, whether novel therapies for clinical application are safe and more effective than the traditional interventions. Studies using the standardized primers are being performed to verify the reduction of $C$. albicans virulence genes expression in clinical samples after application of new therapies to treat oral candidiasis.

\section{Conflict of interest}

All authors declare no conflict of interest.

\section{Funding sources}

The study was supported by a grant from the São Paulo Research Foundation (FAPESP, grant \#2013/07276-1 to A.C.P.) and a scholarship (\#2015/13409-0 to G.C.A.). T.V.S. received a scholarship from the National Counsel of Technological and Scientific Development (CNPq, PIBIC, \#39060). The present research is part of the master's dissertation by G.C.A.

\section{References}

Akpan, A., Morgan, R., 2002. Oral candidiasis. Postgrad. Med. J. 78, 455-459.

Alves, C.T., Wei, X., Silva, S., Azeredo, J., Henriques, M., Williams, D.W., 2014. Candida albicans promotes invasion and colonisation of Candida glabrata in a reconstituted human vaginal epithelium. J. Inf. Secur. 69, 396-407.

Bustin, S.A. (Ed.), 2004. A-Z of Quantitative PCR. International University Line, La Jolla, CA.

Cha, R.S., Thilly, W.G., 1993. Specificity, efficiency, and fidelity of PCR. PCR Methods Appl. 3 (3), S18-S29.

Chatterjee, S., Alampalli, S.V., Nageshan, R.K., Chettiar, S.T., Joshi, S., Tatu, U.S., 2015. Draft genome of a commonly misdiagnosed multidrug resistant pathogen Candida auris. BMC Genomics 16, 686.

Chen, H.F., Lan, C.Y., 2015. Role of SFP1 in the regulation of Candida albicans biofilm formation. PLoS One 10, e0129903.

Dai, B., Wang, Y., Zhao, L., Li, D., Li, M., Cao, Y., Jiang, Y., 2013. Cap1p attenuates the apoptosis of Candida albicans. FEBS J. 280, 2633-2643.

Enjalbert, B., Smith, D.A., Cornell, M.J., Alam, I., Nicholls, S., Brown, A.J.P., Quinn, J., 2006. Role of the Hog1 stress-activated protein kinase in the global transcriptional response to stress in the fungal pathogen Candida albicans. Mol. Biol. Cell 17, 1018-1032.

Finkel, J.S., Mitchell, A.P., 2011. Genetic control of Candida albicans biofilm development. Nat. Rev. Microbiol. 9, 109-118.

Gilfillan, G.D., Sullivan, D.J., Haynes, K., Parkinson, T., Coleman, D.C., Gow, N.A.R., 1998. Candida dubliniensis: phylogeny and putative virulence factors. Microbiology 144, 829-838.

Green, C.B., Cheng, G., Chandra, J., Mukherjee, P., Ghannoum, M.A., Hoyer, L.L., 2004 RT-PCR detection of Candida albicans ALS gene expression in the reconstituted human epithelium (RHE) model of oral candidiasis and in model biofilms. Microbiology 150, $267-275$.

Gulati, M., Nobile, C.J., 2016. Candida albicans biofilms: development, regulation, and molecular mechanisms. Microbes Infect. 18, 310-321.

Haynes, K., 2001. Virulence in Candida species. Trends Microbiol. 9, 591-596.

Hnisz, D., Bardet, A.F., Nobile, C.J., Petryshyn, A., Glaser, W., Schock, U., Stark, A. Kuchler, K., 2012. A Histone Deacetylase adjusts transcription kinetics at coding sequences during Candida albicans morphogenesis. PLoS Genet. 8, e1003118.

Hwang, C.S., Rhie, G., Kim, S.T., Kim, Y.R., Huh, W.K., Baek, Y.U., Kang, S.O., 1999. Copper- and zinc-containing superoxide dismutase and its gene from Candida albicans. Biochim. Biophys. Acta 1427, 245-255.

Jackson, A.P., Gamble, J.A., Yeomans, T., Moran, G.P., Saunders, D., Harris, D., et al., 2009. Comparative genomics of the fungal pathogens Candida dubliniensis and Candida albicans. Genome Res. 19, 2231-2244.

Johnson, M., Zaretskaya, I., Raytselis, Y., Merezhuk, Y., McGinnis, S., Madden, T.M., 2008. NCBI BLAST: a better web interface. Nucleic Acids Res. 36 (Web Server), W5-W9.

Komalapriya, C., Kaloriti, D., Tillmann, A.T., Yin, Z., Herrero-de-Dios, C., Jacobsen, M.D., Belmonte, R.C., Cameron, G., Haynes, K., Grebogi, C., Moura, A.P.S., Gow, N.A.R., Thiel, M., Quinn, J., Brown, A.J.P., Romano, M.C., 2015. Integrative model of oxidative stress adaptation in the fungal pathogen Candida albicans. PLoS One 10, e0137750.

Kulak, Y., Arikan, A., Delibalta, N., 1994. Comparison of three different treatment methods for generalized denture stomatitis. J. Prosthet. Dent. 72, 283-288.

Leidich, S.D., Ibrahim, A.S., Fu, Y., Koul, A., Jessup, C., Vitullo, J., Fonzi, W., Mirbod, F., Nakashima, S., Nozaw, Y., Ghannoum, M.A., 1998. Cloning and disruption of caPLB1, a phospholipase B gene involved in the pathogenicity of Candida albicans. J. Biol. Chem. 273, 26078-26086.

Lyon, J.P., da Costa, S.C., Totti, V.M., Munhoz, M.F., de Resende, M.A., 2006. Predisposing conditions for Candida spp. carriage in the oral cavity of denture wearers and individuals with natural teeth. Can. J. Microbiol. 52, 462-467.

Martchenko, M., Alarco, A., Harcus, D., Whiteway, M., 2004. Superoxide dismutases in Candida albicans: transcriptional regulation and functional characterization of the hyphal-induced SOD5 gene. Mol. Biol. Cell 15, 456-467.

Mayer, F.L., Wilson, D., Hube, B., 2013. Candida albicans pathogenicity mechanisms. Virulence 4, 119-128.

McManus, B.A., Coleman, D.C., Moran, G., Pinjon, E., Diogo, D., Bougnoux, M., et al., 2008. Multilocus sequence typing reveals that the population structure of Candida dubliniensis is significantly less divergent than that of Candida albicans. J. Clin. Microbiol. 46, 652-664.

Monroy-Pérez, E., Sáinz-Espuñes, T., Paniagua-Contreras, G., Negrete-Abascal, E. Rodríguez-Moctezuma, J.R., Vaca, S., 2012. Frequency and expression of ALS and HWP1 genotypes in Candida albicans strains isolated from Mexican patients suffering from vaginal candidosis. Mycoses 55, e151-e157.

Moran, G.P., Coleman, D.C., Sullivan, D.J., 2012. Candida albicans versus Candida 
dubliniensis: why is C. albicans more pathogenic? Int. J. Microbiol., 205921. http://dx. doi.org/10.1155/2012/205921. (7 pages).

Naglik, J.R., Challacombe, S.J., Hube, B., 2003a. Candida albicans secreted aspartyl proteinases in virulence and pathogenesis. Microbiol. Mol. Biol. Rev. 67, 400-428.

Naglik, J.R., Rodgers, C.A., Shirlaw, P.J., Dobbie, J.L., Fernandes-Naglik, L.L., Greenspan, D., Aganian, N., Challacombe, S.J., 2003b. Differential expression of Candida albicans secreted aspartyl proteinase and phospholipase B genes in humans correlates with active oral and vaginal infections. J. Infect. Dis. 188, 469-479.

Nailis, H., Kucharíková, S., Řičicová, M., Dijck, P.V., Deforce, D., Nelis, H., Coenye, T. 2010. Real-time PCR expression profiling of genes encoding potential virulence factors in Candida albicans biofilms: identification of model-dependent and -independent gene expression. BMC Microbiol. 10, 114.

Nobile, C.J., Johnson, A.D., 2015. Candida albicans biofilms and human disease. Annu. Rev. Microbiol. 69, 71-92.

Nobile, C.J., Schneider, H.A., Nett, J.E., Sheppard, D.C., Filler, S.G., Andes, D.R., Mitchell, A.P., 2008. Complementary adhesin function in C. albicans biofilm formation. Curr. Biol. 18, 1017-1024.

Nolan, T., Hands, R.E., Bustin, S.A., 2006. Quantification of mRNA using real-time RTPCR. Nat. Protoc. 1, 1559-1582.

Paranjape, V., Datta, D., 1991. Overexpression of the actin gene is associated with the morphogenesis of Candida albicans. Biochem. Biophys. Res. Commun. 179, 423-427.

Premier Biosoft PCR primer design guidelines. http://www.premierbiosoft.com/tech notes/PCR_Primer_Design.html, Accessed date: 5 October 2017.

Sardi, J.C.O., Scorzoni, L., Bernardi, T., Fusco-Almeida, A.M., Mendes Giannini, M.J.S.,
2013. Candida species: current epidemiology, pathogenicity, biofilm formation, natural antifungal products and new therapeutic options. J. Med. Microbiol. 62, 10-24.

Seleem, D., Chen, E., Benso, B., Pardi, V., Murata, R.M., 2016. In vitro evaluation of antifungal activity of monolaurin against Candida albicans biofilms. PeerJ 4, e2148.

Silva, S., Negri, M., Henriques, M., Oliveira, R., Williams, D.W., Azeredo, J., 2011.

Candida glabrata, Candida parapsilosis and Candida tropicalis: biology, epidemiology, pathogenicity and antifungal resistance. FEMS Microbiol. Rev. 36, 288-305.

Sullivan, D.J., Moran, G.P., Coleman, D.C., 2005. Candida dubliniensis: ten years on. FEMS Microbiol. Lett. 253, 9-17.

Thompson, D.S., Carlisle, P.L., Kadosh, D., 2011. Coevolution of morphology and virulence in Candida species. Eukaryot. Cell 10, 1173-1182.

Thornton, B., Basu, C., 2011. Real-time PCR (qPCR) primer design using free online software. Biochem. Mol. Biol. Educ. 39, 145-154.

Wysong, D.R., Christin, L., Sugar, A.M., Robbins, P.W., Diamond, R.D., 1998. Cloning and sequencing of a Candida albicans catalase gene and effects of disruption of this gene. Infect. Immun. 66, 953-1961.

Yin, J.L., Shackel, N.A., Zekry, A., McGuinness, P.H., Richards, C., et al., 2001. Real-time reverse transcriptase-polymerase chain reaction (RT-PCR) for measurement of cytokine and growth factor mRNA expression with fluorogenic probes or SYBR Green I. Immunol. Cell Biol. 79, 213-221.

Zhu, J., Krom, B.P., Sanglard, D., Intapa, C., Dawson, C.C., Peters, B.M., Shirtliff, M.E., Jabra-Rizk, M.A., 2011. Farnesol-induced apoptosis in Candida albicans is mediated by Cdr1-p extrusion and depletion of intracellular glutathione. PLoS One 6, e28830. 